Bull. Mater. Sci., Vol. 21, No. 4, August 1998, pp. 349-354. (C) Indian Academy of Sciences.

\title{
Beach sand minerals: A new material resource for glass and ceramics
}

\author{
G BANERJEE* \\ Refractories Division. Central Glass and Ceramic Research Institute, Calcutta 700032 , India \\ MS received 13 February 1998; revised 7 May 1998
}

\begin{abstract}
The vast quantities of different beach sand minerals left behind after the extraction of rare earth compounds are industrial wastes. These can be utilized to develop various products in the form of synthetic raw materials or finished product, for applications in glass and ceramic industries. In this paper, the present research work on sillimanite sand, garnet sand and zircon sand are discussed. Attempts have been made to find out the possible uses of these minerals, particularly in the field of glass and ceramic as the materials developed from these minerals are cost competitive. Properties and microstructure of the products developed are systematically discussed.
\end{abstract}

Keywords. Sillimanite; zircon; garnet; beach sand; mullite; aggregate; granite.

\section{Introduction}

The gradual depletion of naturally-occurring raw materials has compelled us to search for alternate materials for synthetic raw materials preparation. India is one of the countries with a long coast line (more than $7600 \mathrm{~km}$ ) with large deposits of beach sand. The heavy minerals, the small crystals or sand grains liberated from the weathering of crystalline rocks, are carried to the sea by the flowing streams. Once the minerals reach the beach, they are acted upon by various coastal processes like coastal current, waves etc which finally determine the mineral deposits distribution and their concentration along the beach. Beach sand minerals contain some rare earths. After the extraction of these rare earths, huge amounts of sand that are left over are nothing but a mechanical mixture of ilmenite, rutile, zircon, sillimanite, garnet and quartz. The other global producers of these mineraks are Australia, S. Africa, USA, USSR, Canada, Norway, Brazil, Malaysia and Sri Lanka. In India, different beach sand minerals are obtained from Indian Rare Earths Limited (IREL).

In the field of glass and ceramics, sillimanite, zircon and garnet are important. Indian reserves of these minerals, compared to the world resources are given in table 1 (Nagar 1995). The various minerals are separated by wet gravity separation followed by dry separation technique, which includes magnetic and electrostatic processes. Extensive research work has already been carried out and is still going on for the effective utilization of these minerals. Utilization of these minerals not only

*MRSI Medal Lecture, Mumbai, 1997 cleans the environment but also saves our valuable naturally-occurring mineral reserves.

\subsection{Sillimanite beach sand}

Chemically it is $\mathrm{Al}_{2} \mathrm{O}_{3} \cdot \mathrm{SiO}_{2}$, containing 63 wt\% $\mathrm{Al}_{2} \mathrm{O}_{3}$ and different types of accessory oxides as impurity. The main impurities present are: $\mathrm{ZrO}_{2}, \mathrm{Fe}_{2} \mathrm{O}_{3}, \mathrm{TiO}_{2}, \mathrm{CaO}$ and $\mathrm{MgO}$. On heating the sillimanite beach sand between $1500^{\circ} \mathrm{C}$ and $1650^{\circ} \mathrm{C}$, it decomposes to mullite and silica (Tripathi and Banerjee 1998).

$$
3\left(\mathrm{Al}_{2} \mathrm{O}_{3} \cdot \mathrm{SiO}_{2}\right)=3 \mathrm{Al}_{2} \mathrm{O}_{3} \cdot 2 \mathrm{SiO}_{2}+\mathrm{SiO}_{2} .
$$

Due to its structural advantage, mullite is the most desirable mineral phase in all high alumina ceramics of the alumino silicate group. The released silica partially reacts with impurities to form a vitreous phase, which impairs the quality of the product. The product quality can be improved by adding alumina to the batch, so that the silica released during thermal decomposition reacts with the alumina to further produce mullite. Two types of sillimanite sand are available from the Indian Rare Earths Limited: OSCOM (O) variety, which is yellowish due to the presence of ferrogeneous coating on them, and QUILON (Q) containing some amounts of zircon. Representative chemical compositions of sillimanite sand are given in table 2. X-ray diffraction pattern (XRD) of the sillimanite sands (O) is given in figure 1 . It is obvious that, mineralogically these are sillimanite associated with small amounts of quartz and zircon as impurities in the OSCOM and QUILON varieties, respectively. However, they are not detrimental to the material properties. 
Table 1. Beach sand mineral resources in India and world.

\begin{tabular}{lccc}
\hline & \multicolumn{2}{l}{ Resources (million tonnes) } & \\
\cline { 2 - 3 } Minerals & India & World & Other producing countries \\
\hline Sillimanite & 54.00 & $454.00^{*}$ & Australia, France, USA, USSR, etc \\
Zircon & 12.00 & 80.00 & Australia, S. Africa, USA, USSR, etc \\
Garnet & 53.00 & 59.00 & Australia, S. Africa, USA, USSR, Zambia, etc \\
\hline
\end{tabular}

*inclusive of kyanite

Table 2. Chemical analysis of different Indian beach sands.

\begin{tabular}{|c|c|c|c|c|c|}
\hline \multirow{2}{*}{$\begin{array}{l}\text { Constituent } \\
\text { (wt\%) }\end{array}$} & \multicolumn{2}{|c|}{ Sillimanite sand } & \multicolumn{2}{|c|}{ Zircon sand } & \multirow{2}{*}{$\begin{array}{r}\text { Garne } \\
\text { sand }\end{array}$} \\
\hline & (O) & (Q) & Sand & Flour & \\
\hline $\mathrm{Al}_{2} \mathrm{O}_{3}$ & 57.60 & $60 \cdot 37$ & - & $6 \cdot 76$ & 19.09 \\
\hline $\mathrm{SiO}_{2}$ & $40 \cdot 30$ & $36 \cdot 22$ & $32 \cdot 20$ & 32.00 & $36 \cdot 15$ \\
\hline $\mathrm{TiO}_{2}$ & $0 \cdot 11$ & - & 0.60 & - & 0.67 \\
\hline $\mathrm{Fe}_{2} \mathrm{O}_{3}$ & $0 \cdot 31$ & 0.27 & 0.08 & $0 \cdot 17$ & 32.87 \\
\hline $\mathrm{ZrO}_{2}$ & - & 0.61 & 65.90 & $59 \cdot 70$ & - \\
\hline $\mathrm{CaO}$ & 0.42 & $1 \cdot 36$ & - & 1.03 & $3 \cdot 41$ \\
\hline $\mathrm{MgO}$ & $0 \cdot 31$ & tr. & - & - & $7 \cdot 22$ \\
\hline $\mathrm{Na}_{2} \mathrm{O}$ & 0.02 & 0.06 & $0 \cdot 10$ & - & - \\
\hline LOI & 0.70 & 0.50 & $0 \cdot 20$ & 0.20 & 0.29 \\
\hline
\end{tabular}

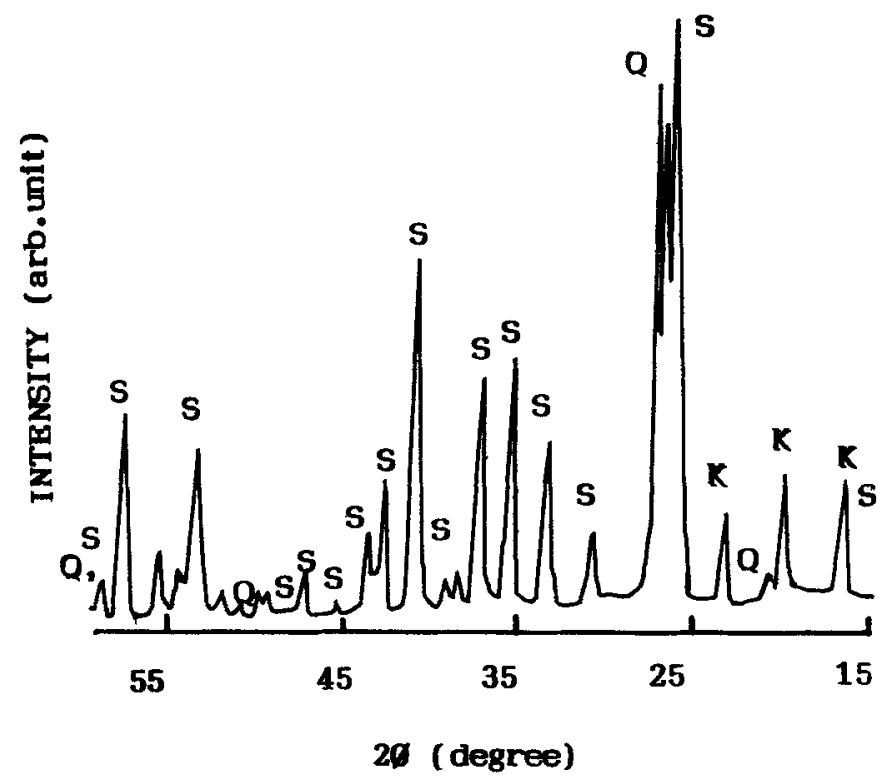

Figure 1. X-ray $(\mathrm{CuK} \alpha)$ diffraction pattern of sillimanite beach sand showing the presence of quartz $(Q)$ and kaolinite $(K)$ as impurity.

Technologies have been developed to produce high alumina aggregate for refractories applications, whether it is shaped or unshaped. Synthetic mullite aggregate was developed by reaction sintering of sillimanite sand and calcined alumina. The average properties of this aggregate
Table 3. Typical composition and properties of synthetic refractory aggregate.

\begin{tabular}{lcc}
\hline Properties & Synthetic mullite & Zirconia-mullite \\
\hline $\begin{array}{l}\text { Chemical composition } \\
\text { (wt\%) }\end{array}$ & & \\
$\mathrm{Al}_{2} \mathrm{O}_{3}$ & $70-74$ & $48-55$ \\
$\mathrm{SiO}_{2}$ & $24-26$ & $16-20$ \\
$\mathrm{Fe}_{2} \mathrm{O}_{3}$ & $0 \cdot 5-0.7$ & - \\
$\mathrm{ZrO}_{2}+\mathrm{HfO}_{2}$ & - & $25-36$ \\
Bulk density (g/cc) & $2 \cdot 85-2.92$ & $3 \cdot 1-3.6$ \\
App. open porosity (\%) & $1-4$ & $1-4$
\end{tabular}

Mineral phases Major: Mullite Mullite, zirconia Minor: $\alpha$-alumina

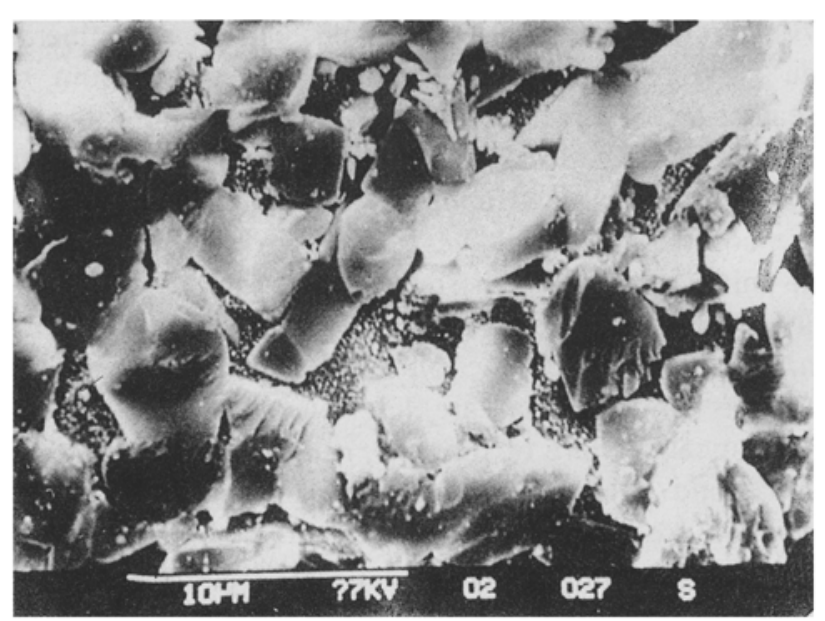

Figure 2. Scanning electron micrograph of the mullite aggregate developed from sillimanite sand.

are given in table 3. Microstructural evaluation by SEM (figure 2) shows that it contains orthorhombic mullite crystals interlocking with each other, and associated with small amounts of intergranular vitreous phase. Very small amounts of secondary corundum phases are also noticed in the interstitial spaces. The superior thermomechanical properties of these aggregates depend on this compact microstructure. Since it is very difficult to distinguish mullite from sillimanite by XRD due to the close simi- 
larity in the diffraction pattern, IR technique was used to identify the mullite (Roy and Francis 1953; Chaudhury 1981). Figure 3 depicts the IR pattern of the sintered mullite (M) aggregate. The absence of the characteristic sillimanite absorption peak at $1175 \mathrm{~cm}^{-1}$ indicates that there is almost complete conversion of sillimanite to mullite.

Sillimanite sand has potential application in the field of ceramic fibre. Technologies exist for producing alumino-silicate ceramic fibre, used as insulating material. Low cost, very low thermal conductivity and adequate refractoriness account for the increasing use of this material. Recently, $\mathrm{ZrO}_{2}$-containing alumino-silicate fibres were used as insulating materials at high temperatures. Sillimanite beach sand are also used in the production of high alumina refractories and high temperature insulating brick. Typical properties of these products are given in table 4. All these products find application in metallurgical, glass, cement, petrochemical industries etc.

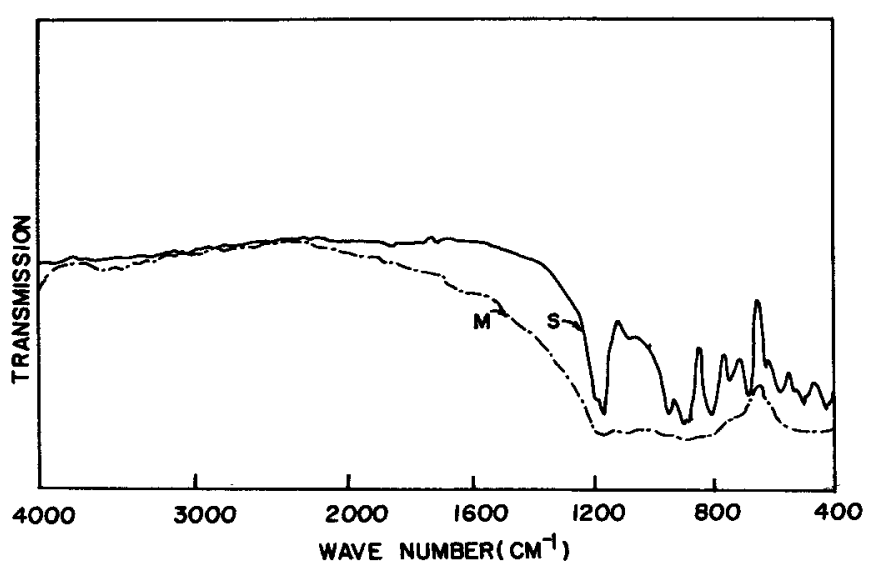

Figure 3. IR spectra of the sillimanite sand (S) and mullite (M) developed from this sand.

Table 4. Chemical composition of refractories made from sillimanite sand.

\begin{tabular}{lcc}
\hline Properties & High alumina & $\begin{array}{c}\text { High temp. } \\
\text { insulation }\end{array}$ \\
\hline $\begin{array}{l}\text { Chemical composition } \\
(\mathrm{wt} \%)\end{array}$ & & \\
$\mathrm{Al}_{2} \mathrm{O}_{3}$ (min.) & 60 & $58-60$ \\
$\mathrm{Fe}_{2} \mathrm{O}_{3}(\mathrm{max})$. & 0.5 & $0.2-0.5$ \\
$\mathrm{CCS}\left(\mathrm{kg} / \mathrm{cm}^{2}\right)$ & $450-600$ & $45-50$ \\
$\mathrm{PLCR}$ at $1500^{\circ} \mathrm{C}(\%)$ & $* 1-1.5 \%$ & $<1.25 \%$ \\
Thermal spalling & $>30 \mathrm{cycle}$ & - \\
Thermal conductivity & & $0.0009956-$ \\
$\left(\mathrm{g} \mathrm{cal} \mathrm{sec} \mathrm{cm}^{2} \mathrm{deg}^{-1} \mathrm{~cm}\right)$ & & 0.001029 \\
\hline
\end{tabular}

*at $1600^{\circ} \mathrm{C}$

\subsection{Zircon beach sand}

Chemically, it is $\mathrm{ZrSiO}_{4}$ with small amounts of impurities like $\mathrm{Al}_{2} \mathrm{O}_{3}, \mathrm{TiO}_{2}$ and $\mathrm{CaO}$. The XRD pattern of zircon sand (figure 4), indicates the presence of rutile as impurities. Zircon sand is available in the market in two forms: the zircon sand, and the zircon flour. Latter is a fine powder obtained by vibrogrinding zircon sand in $\mathrm{Al}_{2} \mathrm{O}_{3}$-lined jet mill. A typical composition of zircon sand and zircon flour used in various glass and ceramic-related products, is given in table 2 . From this table it appears that zircon flour contains about $6.76 \mathrm{wt} \%$ $\mathrm{Al}_{2} \mathrm{O}_{3}$ and consequently, $\mathrm{ZrO}_{2}$ content is less. This is due to incorporation of $\mathrm{Al}_{2} \mathrm{O}_{3}$ into the material from the alumina lining of the jet mill, during grinding operation.

Heating the zircon sand to $1700^{\circ} \mathrm{C}$, dissociation into zirconia and silica occurs, represented by the following reaction (Banerjee et al 1995):

$$
\mathrm{ZrSiO}_{4}=\mathrm{ZrO}_{2}+\mathrm{SiO}_{2}
$$

On addition of alumina, the liberated $\mathrm{SiO}_{2}$ reacts with $\mathrm{Al}_{2} \mathrm{O}_{3}$ to form mullite $\left(3 \mathrm{Al}_{2} \mathrm{O}_{3} \cdot 2 \mathrm{SiO}_{2}\right)$, releasing $\mathrm{ZrO}_{2}$. Thus, the mullite-zirconia composites can be developed by reaction sintering of zircon and alumina in the temperature range $1400-1600^{\circ} \mathrm{C}$. The reaction is represented as

$$
2 \mathrm{ZrSiO}_{4}+3 \mathrm{Al}_{2} \mathrm{O}_{3}=3 \mathrm{Al}_{2} \mathrm{O}_{3} \cdot 2 \mathrm{SiO}_{2}+2 \mathrm{ZrO}_{2} \text {. }
$$

Average properties of the synthetic mullite-zirconia aggregate made from zircon sand and alumina are provided in table 3 . This aggregate also finds application in shaped or monolithic refractories, which can be used

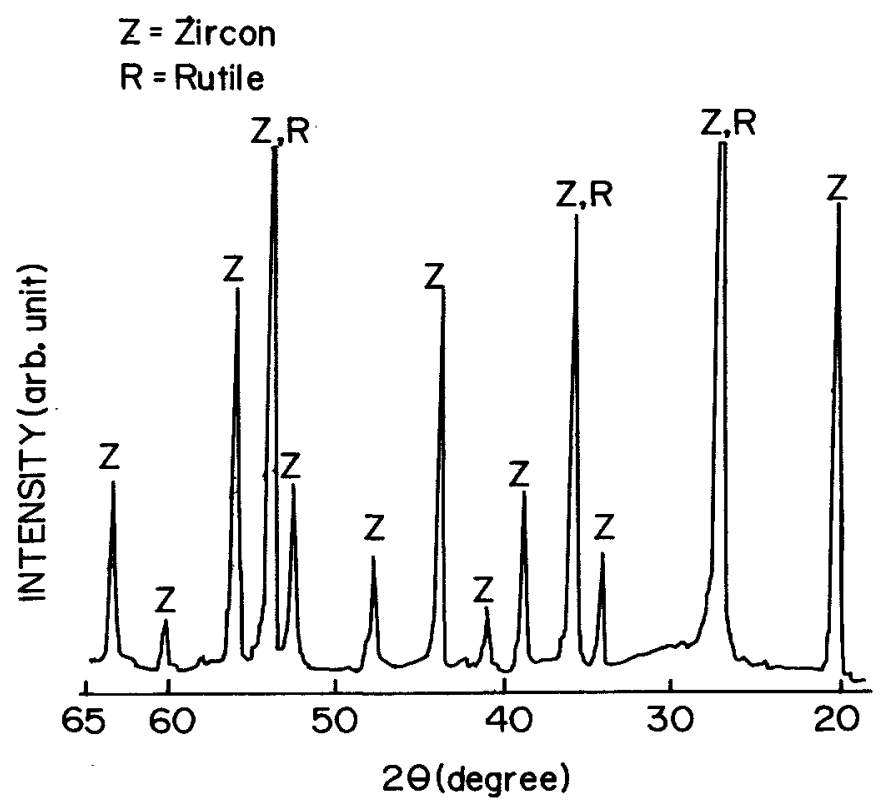

Figure 4. X-ray $(\mathrm{CuK} \alpha)$ diffraction pattern of the zircon sand. 
in glass industries. Microstructure of the mullite-zirconia aggregates (figure 5) shows columnar mullite grain with subrounded to rounded zirconia embedded in mullite. Zirconia occupies the intergranular as well as intragranular positions in the mullite matrix. XRD studies on the aggregate developed shows that the major crystalline phases were mullite and zirconia, both monoclinic and tetragonal (figure 6).

Another application of zircon sand is in the production of zirconia, a major raw material for the production of advanced refractories and structural ceramic products. Technology already exists to extract $\mathrm{ZrO}_{2}$ from the zircon sand by basic sulphate process (Chatterjee et al 1992). For the production of zirconia refractories, partiallystabilized zirconia formed by the addition of stabilizing agents e.g. $\mathrm{CaO}, \mathrm{MgO}, \mathrm{Y}_{2} \mathrm{O}_{3}$ and $\mathrm{CeO}_{2}$ are used. Using this zirconia, green bricks are fabricated by isostatic pressing, followed by sintering at a temperature of $\sim 2000^{\circ} \mathrm{C}$ to develop zirconia refractories. The microstructure consists of directly bonded cubic zirconia with

Table 5. Properties of zircon and stabilized zirconia refractories,

\begin{tabular}{|c|c|c|}
\hline Properties & Zircon & Stabilized zirconia \\
\hline \multicolumn{3}{|l|}{$\begin{array}{l}\text { Chemical composition } \\
\text { (wt\%) }\end{array}$} \\
\hline $\mathrm{ZrO}_{2}(\mathrm{~min})$ & $60 \cdot 0$ & 95.0 \\
\hline $\mathrm{SiO}_{2}$ & $33 \cdot 0$ & - \\
\hline Bulk density $(\mathrm{g} / \mathrm{cc})$ & $3 \cdot 8-3 \cdot 9$ & $4 \cdot 8-4 \cdot 9$ \\
\hline App. porosity (\%) & $<15$ & $<20$ \\
\hline $\operatorname{MOR}\left(\mathrm{N} / \mathrm{mm}^{2}\right)$ & $>16$ & $>70$ \\
\hline Refractoriness $\left({ }^{\circ} \mathrm{C}\right)$ & $2550-2600$ & 2424 \\
\hline $\begin{array}{l}\text { Basic slag resistance } \\
\text { (\% wear) }\end{array}$ & 1 & 20 \\
\hline $\begin{array}{l}\text { Ther. exp. coeff. }(\%) \\
\left(0-1500^{\circ} \mathrm{C}\right)\end{array}$ & $4 \cdot 7$ & $6 \cdot 0$ \\
\hline
\end{tabular}

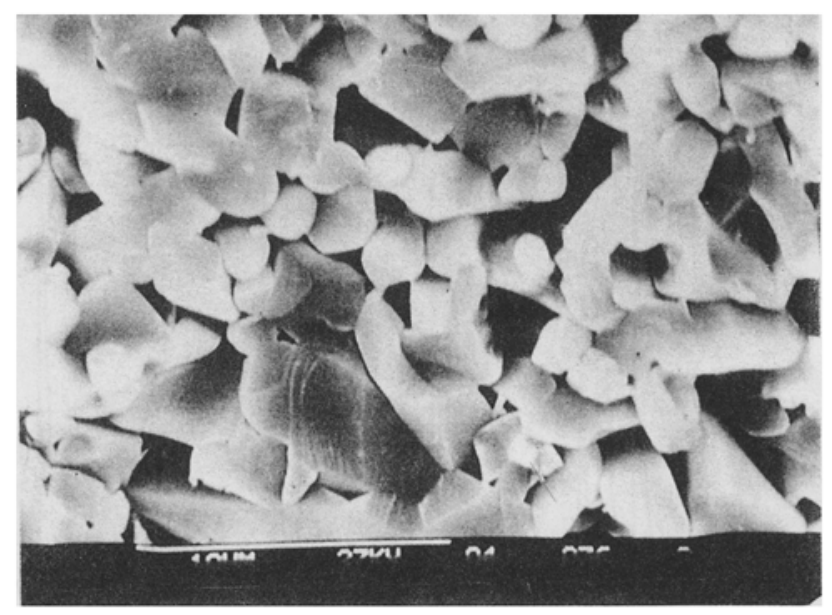

Figure 5. Scanning electron micrograph of the zirconia-mullite aggregate developed from zircon sand showing rounded to subrounded zirconia embedded in mullite matrix. monoclinic zirconia phases, and presence of very fine micropores are also noticed in the microstructure. Typical properties of zircon and stabilized zirconia refractories are summarized in table 5 .

\subsection{Gamet sand}

Garnets are a family of tertiary silicates; $\mathrm{A}_{3} \mathrm{~B}_{2}\left(\mathrm{SiO}_{4}\right)_{3}$, where $\mathrm{A}$ is a bivalent metal like $\mathrm{Ca}, \mathrm{Mg}, \mathrm{Fe}$ etc and $\mathrm{B}$ is a trivalent metal like $\mathrm{Fe}, \mathrm{Al}, \mathrm{Ti}$ etc Much of this garnet is a solid solution of almandine $\mathrm{Fe}_{3} \mathrm{Al}_{2}\left(\mathrm{SiO}_{4}\right)_{3}$, and pyrope $\mathrm{Mg}_{3} \mathrm{Al}_{2}\left(\mathrm{SiO}_{4}\right)_{3}$, and are referred to as pyralspites. The hardness of this sand varies from 6.4 to 7.5 on the Moh's scale. The chemical analysis of the garnet sand is given in table 2 . These garnets have a very high Fe content, being almandine garnet. XRD pattern of this sand confirms the occurrence of almandine-pyrope garnet (figure 7).

Due to its high hardness, the use of garnet as an abrasive is in moderate demand. Powdered garnet sand

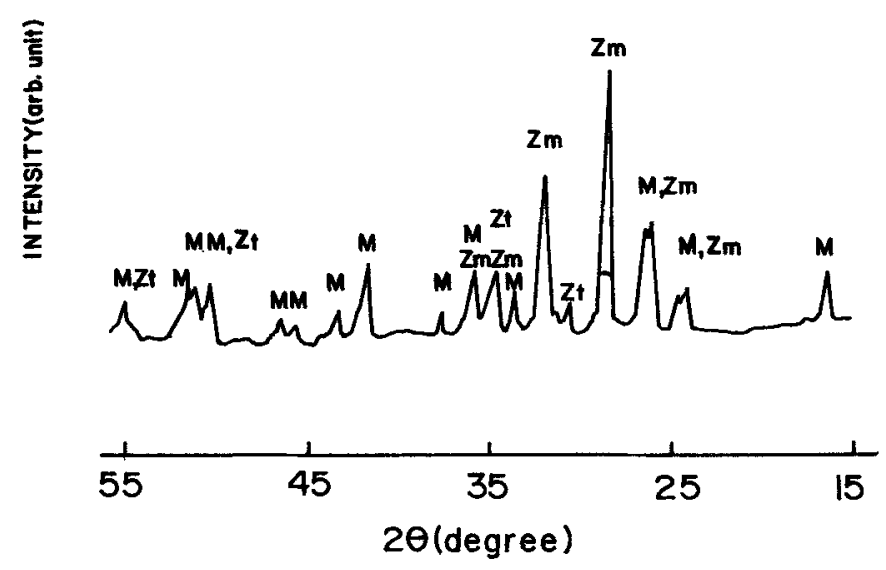

Figure 6. X-ray $(\mathrm{CuK} \alpha)$ diffraction of the zirconia-mullite aggregate.

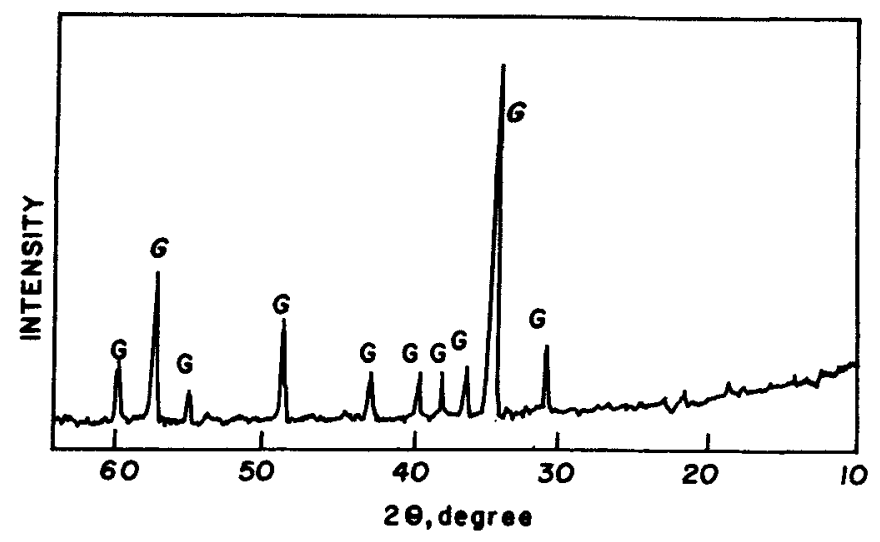

Figure 7. $\mathrm{XRD}(\mathrm{CuK} \alpha)$ of the garnet sand showing almendinepyrope (G) nature of this sand. 
is used for polishing glass and TV tubes. Technologies exist to produce dense abrasion-resistant tiles with high strength, which are suitable for industrial flooring (Kumar et al 1992). This garnet sand when mixed with potash feldspar and clay together with oxide pigments ground, followed by pressing into tiles using suitable binder, and sintered at a temperature of $1200-1250^{\circ} \mathrm{C}$, produces synthetic granite tiles. The properties of those synthetic tiles are comparable and to some extent superior to the natural granite. Comparative properties of the synthetic granite and natural granite tiles are given in table 6 . Moreover, since the cost of production of synthetic granite tiles is much less than that of natural one, this technique has tremendous potential in future. Microstructure of natural granite (figure 8A) shows that it mainly consists of feldspar and quartz. Here the quartz grains are coarse in nature and anhedral shaped, closely associated with plagioclase and microcline feldspar grains. The rock shows a interlocking mosaic texture. Optical photomicrograph (figure $8 \mathrm{~B}$ ) of synthetic granite shows

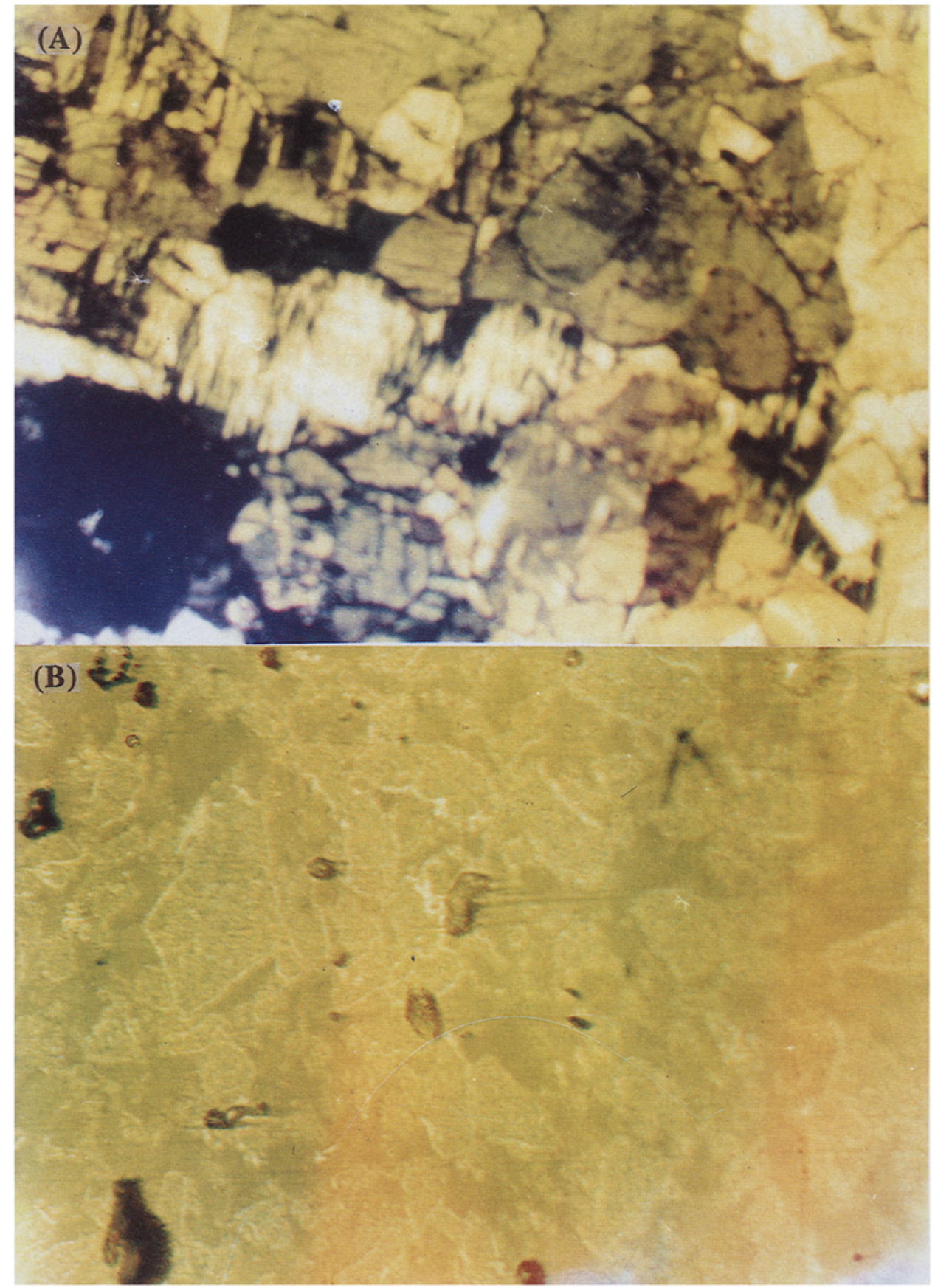

Figure 8. Optical micrograph of (A) natural granite and (B) synthetic granite. 
Table 6. Comparative properties of natural granite and synthetic granite.

\begin{tabular}{lcc}
\hline Properties & Natural granite & Synthetic granite \\
\hline App. porosity (\%) & $5-6$ & $>1$ \\
Abr. resistance & - & $0 \cdot 16-0 \cdot 20$ \\
Sp. gr. & - & $2 \cdot 77-2 \cdot 84$ \\
Bulk density (g/cc) & $2 \cdot 56$ & $2 \cdot 78-2 \cdot 88$ \\
Hardness. & $5-6$ & $6-7$ \\
(Moh's scale) & 18 & $45-53$ \\
MOR (MPa) & 200 & $300-330$ \\
CCS (MPa) & - & $12-14$ \\
Charpy impact test & & \\
(N/mm ${ }^{2}$ ) & Per 5 g sample & Per 5 g sample \\
Alkalinity test as per & $0.45 \mathrm{ml} 0.01 \mathrm{~N} \mathrm{HCl}$ & $0.15 \mathrm{ml}$ of $0.01 \mathrm{~N} \mathrm{HCl}$ \\
IS: $2303-1963$ & Passed type I & Passed type I \\
Acid resistance as per & Loss 1.68 & Loss 0.77 \\
IS: $4860-1968(\%)$ & & \\
\hline
\end{tabular}

that it is made up of angular to subangular large grains with prominent grain boundaries distributed throughout the silicate matrix. The larger garnet grains are broken into smaller pieces along the fracture planes so that the grain size varies within the silicate matrix. Grain with criscross exsolution structure is a spinel phase in which $\mathrm{Mg}$ is being replaced by $\mathrm{Fe}$ in most cases.

\section{Conclusion}

Vast deposits of beach sand minerals containing rare earth elements, titanium and zirconium compounds are now attracting attention of scientists and technologists for exploitation of these minerals on a larger scale. Huge amounts of sillimanite, zircon and garnet sands are obtained as by-products during extraction of the rare earth compounds from these sands. The use of these sands not only cleans the environment but also saves valuable energy and natural resources. Sillimanite sand is used to develop synthetic mullite aggregate for refractories application or as such can be used to produce insulating, high alumina and castable refractories. Zircon sand is used in refractories, ceramics and chemical industries. Technology is available to extract zirconia from this sand. Stabilized zirconia has emerged as a structural and refractories material. Garnet sand is now used as an abrasive material for glass polishing. It may have potential application in the production of synthetic granite tiles in the near future, due to its low cost of production and environmental-friendly operation.

\section{Acknowledgement}

The authors thank the Director, Central Glass and Ceramic Research Institute, Calcutta, for his keen interest.

\section{References}

Banerjee G, Tripathi H S, Das K and Das S K 1995 in Handbook of ceramics (Calcutta: Kumar and Associates) vol. II p. 239

Chatterjee M, Ray J, Chatterjee A and Ganguli D 1992 Ceram. Int. 18337

Chaudhury S P 1981 Interceram 3199

Kumar A, Das D K, Chatterjee A, Adhikari U B, Halder S and Banerjee G 1992 Proceedings of AUSTCERAM 92 (Melbourne: Australasian Ceramic Society) 21150

Nagar M S 1995 J. Mines, Metals \& Fuels 396

Roy R and Francis E E 1953 Am. Miner. 38725

Tripathi H S and Banerjee G 1998 Ceram. Int. '(in press)

Tripathi H S, Das S K and Banerjee G 1996 in Proceedings of 2nd India int. refract. congr. (Calcutta: Indian Refractory Makers Association) 2 p. 219 